\title{
THE GEOCHEMICAL DIVERSITY OF LACUSTRINE SEDIMENTS OF THE SUCHEDNIÓW WATER RESERVOIR (ŚWIĘTOKRZYSKIE VOIVODESHIP, POLAND) - PRELIMINARY RESULTS
}

\author{
DOI: https://doi.org/10.18509/AGB217-40159k
}

UDC: $550.42 .08: 551.312 .4 .051(438)$

Tomasz Kalicki $^{1}$, Rafał Kozłowski ${ }^{2}$, Paweł Przepióra ${ }^{1}$, Mirosław Szwed ${ }^{2}$

\begin{abstract}
${ }^{I}$ Department of Geomorphology and Geoarchaeology, Institute of Geography and Environmental Sciences, Jan Kochanowski University in Kielce, Poland

${ }^{2}$ Department of Environmental Research and Geoinformation, Institute of Geography and Environmental Sciences, Jan Kochanowski University in Kielce, Poland Poland
\end{abstract}

corresponding author:

submitted: 17.01 .2021

accepted: 09.03.2021

published: 20.07 .2021

\begin{abstract}
The research area is located in central Poland, in the Świętokrzyskie Voivodeship (Kielce-Sandomierz Upland). Once heavily industrialized as the former Old Polish Industrial District area, there were many forges and iron furnances developed here. For this purpose, on many rivers of this area the industrial ponds were built. They functioned mainly until the collapse of the metallurgical industry and the water mills as well. Built in 1974 on the Kamionka River in Suchedniów, the water reservoir was use for retention and recreational purposes. Since its construction, the reservoir has never been thoroughly dredged. In 2017, large-scale hydrotechnical works on the reservoir began, aimed at its deepening. Draining the Suchedniów water reservoir made it possible to carry out detailed sedimentological and morphological analyzes of its bottom. A large differentiation of the sedimentary environment types in the reservoir basin has been recognized. The collected samples also provided material for geochemical analyzes. The analysis was made for the content of such trace elements as $\mathrm{Pb}, \mathrm{Cd}, \mathrm{Cr}$, $\mathrm{Co}, \mathrm{Cu}, \mathrm{Mn}, \mathrm{Ni}, \mathrm{Zn}, \mathrm{Sr}, \mathrm{As}, \mathrm{Al}$ and $\mathrm{Fe}$. The known industrial history of this area and the use of the modern reservoir, allows to attempt explain the content changes in the lacustrine sediments
\end{abstract}

Keywords: sedimentology, Suchedniów water reservoir, lacustrine sediments, geochemical diversity, Old Polish Industrail District

\section{INTRODUCTION}

The Holy Cross Mountains area is known from the Prehistorical metallurgical activity during the Roman period [1], [2], as well in the modern period [3]. In the Middle Ages, many forges and water mills were built on the Holy Cross Mountains rivers, on which many smaller ponds were built as the part of hydrotechnical structure. The area was developed because of the rich iron ore deposits, which were mined from the nearby hills [4]. The ore was processed in blast furnances and forges that operated in the Old Polish Industrial District area. In Kamionka, as on many other rivers of this region, they were created anthropogenic small-scale water retention system (ASWRS)[5]. The fall of metallurgy at the beginning of the 20th c. led to the disappearance of ASWRS. In the place of some of the old ponds were built bigger reservoirs, just like at Suchedniów [6]. The Suchedniów water reservoir was built in 1974 in the middle section of Kamionka
River in N of Świętokrzyskie Voivodeship, Poland [7](Fig. 1). During the hydrotechnical works in 2017 the reservoir was drained, giving the opportunity to study of morphology and sediments accumulated for over 40 years in its bottom. The study of heavy metals content in alluvia may indicate long-term changes in river pollution caused by variable anthropogenic influence. Moreover, heavily contaminated sediments may be a potential source of secondary pollution in the future. This problem is marked in the case of water reservoirs that gradually silting. In non-industrialized areas, the composition of sediments accumulating on the reservoir bottom, including the content of heavy metals, depends primarily on the lithology of a given catchment and the climatic conditions that determine the weathering processes and the elements release. The enrichment of heavy metals in water sediments observed in industrialized areas 
is primarily the result of human activities: sewage discharge, emission of pollutants into the atmosphere, which, along with precipitation and surface runoff from areas under the pressure of these emissions, get into surface waters [8], [9], [10], [11].

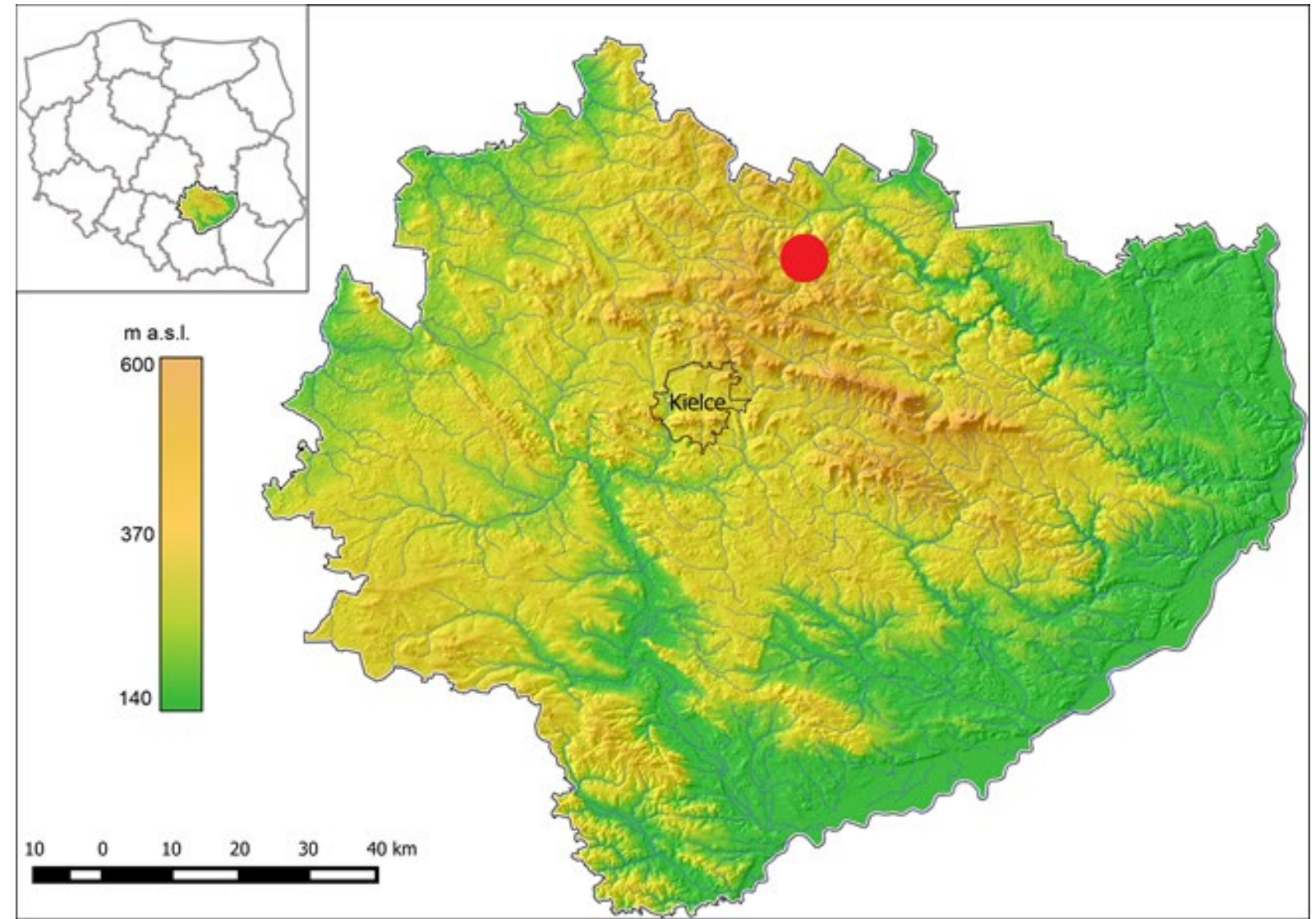

Figure 1. Location of the study area on Digital Elevation Model (DEM)

(By M. Frączek based on date from CODGiK: MGGP Aero, Nr GI-FOTO.703.44.2014)

\section{AIM OF THE STUDY AND METHODS}

The aim of the research was to obtain data about the forms and sediments accumulated in the Suchedniów water reservoir and to capture the diversity of geochemical and sedimentary environments in its basin.

Field work was based on opencast profiles and drillings (using a hand drill and COBRA impact drill). The obtained material was analyzed in grain size terms using sieve and laser method (Mastersizer 3000), pH and geochemical measurement. Basic $\mathrm{pH}$ analyzes of the sediments and the content of trace elements (heavy metals) such as $\mathrm{Pb}, \mathrm{Cd}, \mathrm{Cr}, \mathrm{Co}, \mathrm{Cu}, \mathrm{Mn}, \mathrm{Ni}, \mathrm{Zn}, \mathrm{Sr}, \mathrm{As}, \mathrm{Al}$ and $\mathrm{Fe}$ were performed. Samples collected in the field were analyzed at the "Geomorphological and Hydrological Laboratory” and „Environmental Research Laboratory" of the Jan Kochanowski University in Kielce. In order to determine the chemical composition of heavy metals, the samples were mineralized in the Multiwave 3000 Aanton Paar mineraliser. For this purpose, a sample containing $0.1 \mathrm{~g}$ was weighed and mineralized with nitric acid V (Suprapur Merck 65\%) and perhydrol $(30 \%)$ in a volume ratio of 2.5:1 (microwave power: $1400 \mathrm{~W}$, temperature: $2000 \mathrm{oC}$, time: $40 \mathrm{~min}$ ). After mineralization, the samples were analyzed using the ICP-MS-TOF OptiMass 9500 mass spectrometer (GBC Scientific Equipment, Melbourne, Australia). In order to control the quality of obtained results, certified reference materials such as ERM-CA713 were used.

Based on this data prepared sedimentary, $\mathrm{pH}$ and geochemical map using information obtain from 45 profiles and geological drillings made in the entire reservoir area (samples from the $20 \mathrm{~cm}$ depth were used). These materials have been developed using QGIS and Corel Draw program. 


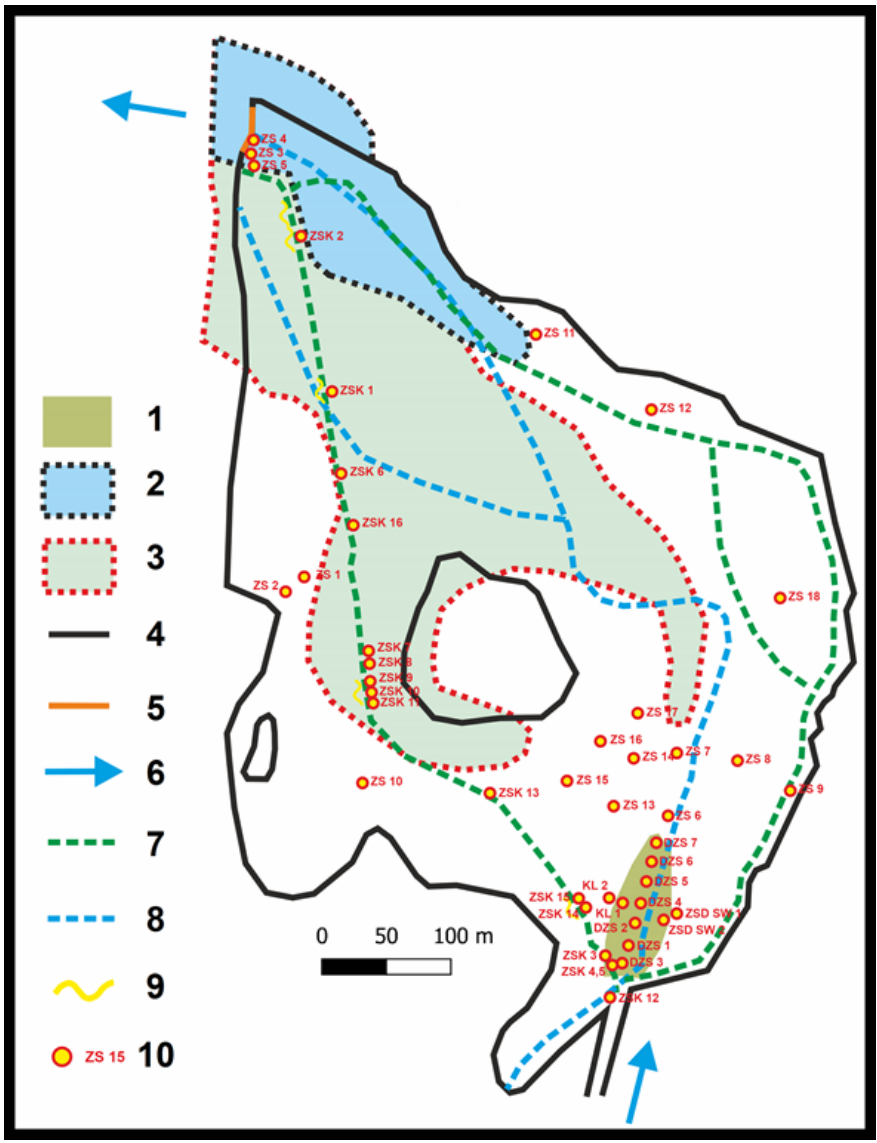

Figure 2. Map of Suchedniów water reservoir:

1 - delta, 2 - water reservoir in 1907-1914, 3 - water reservoir in 1855-1907,

4 - border of modern water reservoir, 5 - dam, 6 - river flow, 7 - drainage channels in 2017,

8 - riverbed before 1974, 9 - mega ripplemarks, 10 - profiles and drillings

In accordance with the adopted geochemical method, the following indicator was employed: geoaccumulation index (Igeo), to assess the pollution of the bottom sediments with heavy metals. The (Igeo) makes it possible to evaluate pollution by comparing current amounts of heavy metals in bottom sediments with the so-called preindustrial concentrations [12], [13]:

Igeo $=\log 2 \mathrm{Cn} / 1,5 \cdot \mathrm{Bn}$

For each metal, the Igeo is classified as:

\section{RESULTS}

The Suchedniów water reservoir was built on the former forge industrial pond area (Fig. 2) and part of the former Kamionka floodplain. After the current reservoir was built, it operated for about 40 years before it was completely drained during hydrotechnical works in order to deepening it. Draining the reservoir revealed the forms and sediments in the bottom [14], [15], [16], [17], as well as many Anodonta anatina shells (Fig. 3), which are an excellent marker of the water cleanliness (bioindicator). During the field work, 45 profiles and boreholes were made (Fig. 2). The samples was collected from the bottom of the reservoir to a depth of $20 \mathrm{~cm}$ for sedimentological
- Igeo class „,0" unpolluted (Igeo $\leq 0$ ),

- Igeo class „1" unpolluted to moderately polluted $(0<$ Igeo $\leq 1)$,

- Igeo class „2" moderately polluted $(1<$ Igeo $\leq 2)$, - Igeo class , ,3" moderately to highly polluted $(2<$ Igeo $\leq 3$ );

- Igeo class ,4” highly polluted $(3<$ Igeo $\leq 4)$,

- Igeo class „,5" highly to very highly polluted ( $4<$ Igeo $\leq 5$ ),

- Igeo class „6” very highly polluted (Igeo $\geq 5$ ).

and geochemical analysis. The Suchedniów water reservoir is a typical flow-through lake used to small retention [19], tourist and recreational purposes. The distribution of sediments on its bottom is quite diverse. There is usually an accumulation of finer sediments in the Kamionka estuary into the reservoir. The sands and sandygravel with an admixture of silty sediments concentrate in the central and northern part of the reservoir. In the western and north-western part the sediments have the most acidic $\mathrm{pH}$, while a small fragment of the bottom near the dam is neutral $\mathrm{pH}$. The average concentrations of trace metals in the analyzed bottom sediment samples are presented in 
the following decreasing sequence $\mathrm{Al}>\mathrm{Fe}>\mathrm{Mn}>\mathrm{Zn}>\mathrm{Sr}>\mathrm{Pb}>\mathrm{Ni}>\mathrm{Cr}>\mathrm{Cu}>\quad \mathrm{Co}>\mathrm{As}>\mathrm{Cd}$. The highest values were recorded for $\mathrm{Al}$ (138328.5 mg.kg-1 dry mass) and Fe (22705.4 mg.kg-1 dry mass), the values of the variation coefficient were the highest for $\mathrm{Cd}$ (120.16) and $\mathrm{Cu}$ (62.42).

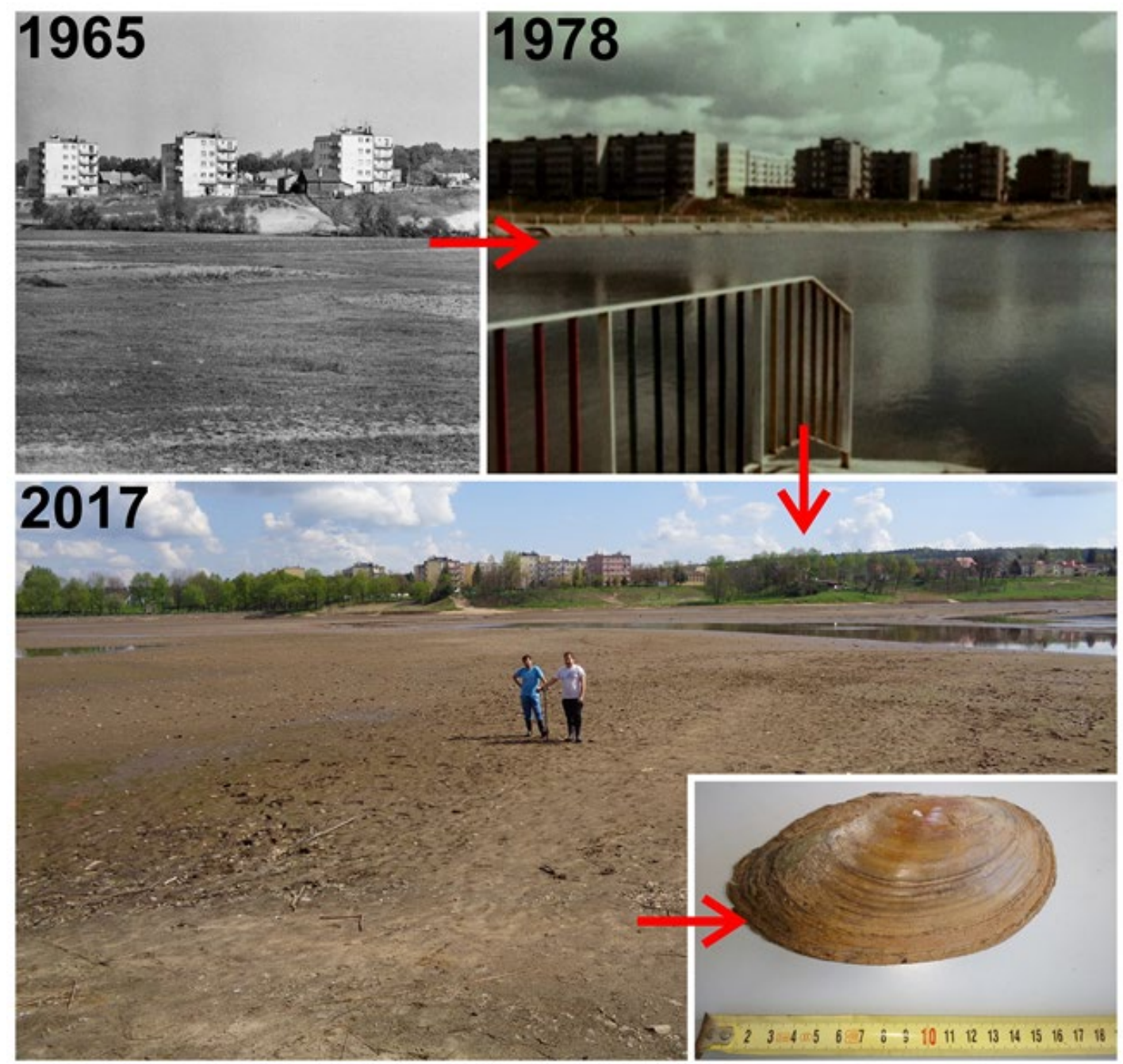

Figure 3. The former flood plain area visible in 1965 and the same area after building the Suchedniów water reservoir in 1978 [18]. Dry reservoir area after hydrotechnical works in 2017 with visible many Anodonta anatina in the bottom (photo by P. Przepióra 2017)

Calculated Igeo [12] in relation to the geochemical background for Poland [21] allowed to classify the analyzed samples into particular classes (Tab. 1). It was shown that the mean values of the Igeo for $\mathrm{Zn}$ and $\mathrm{Cd}$ qualified the analyzed samples as moderately heavily contaminated. In turn, the concentrations of $\mathrm{Co}, \mathrm{Cu}, \mathrm{Mn}, \mathrm{Ni}$ and $\mathrm{As}$ are classified as slightly and moderately polluted. The lowest value of geoaccumulation was calculated for the average concentrations of $\mathrm{Pb}, \mathrm{Cr}$ and $\mathrm{Sr}$ which allows to classify them as practically unpollute.

\section{DISCUSSION}

The many Anodonta anatina shells that were leaved at the bottom of the drained Suchedniów water reservoir. As the excellent bioindicator these mollusks evidenced the relatively high water quality. However, the performed sedimentological and geochemical analyzes showed a very large
Similar classes were divided for the maximum values of the Igeo. The highest values were recorded for $\mathrm{Cd}$ and $\mathrm{Zn}$, and therefore these samples were classified to the 5th class (highly contaminated to very heavily contaminated). The research carried out within the reservoir showed spatial differentiation (Fig. 5). The highest contents of the analyzed metals were found in the southwestern and northern part of the reservoir, where the dam is located.

differentiation of the sediment types at the bottom of the reservoir. Some of them were related to catastrophic events [20] but another with secular processes and long-term human activity. This is also confirmed by geochemical analysis of the sediments, which in the case of selected trace 
elements showed a high level of contamination. The level of contamination is uneven throughout the entire bottom of the reservoir, which may be related

to the overall water circulation of the flow-through reservoir type. Where the water is still, sediments with pollutants supplied by the river from the upper parts of the catchment area are accumulated, while at the place where the delta was formed (high flow energy) in the Kamionka river estuary, these pollutants were washed away. The research carried out [22] on the Suchedniów water reservoir showed similar values of geoaccumulation indicators, but apart from $\mathrm{Cd}, \mathrm{Zn}$ and $\mathrm{Cu}$, an increased value for $\mathrm{Pb}$ was found (class 1). The highest concentration of pollutants can be noted in the northern and western parts of the reservoir, where the $\mathrm{pH}$ of the sediments is very acidic.

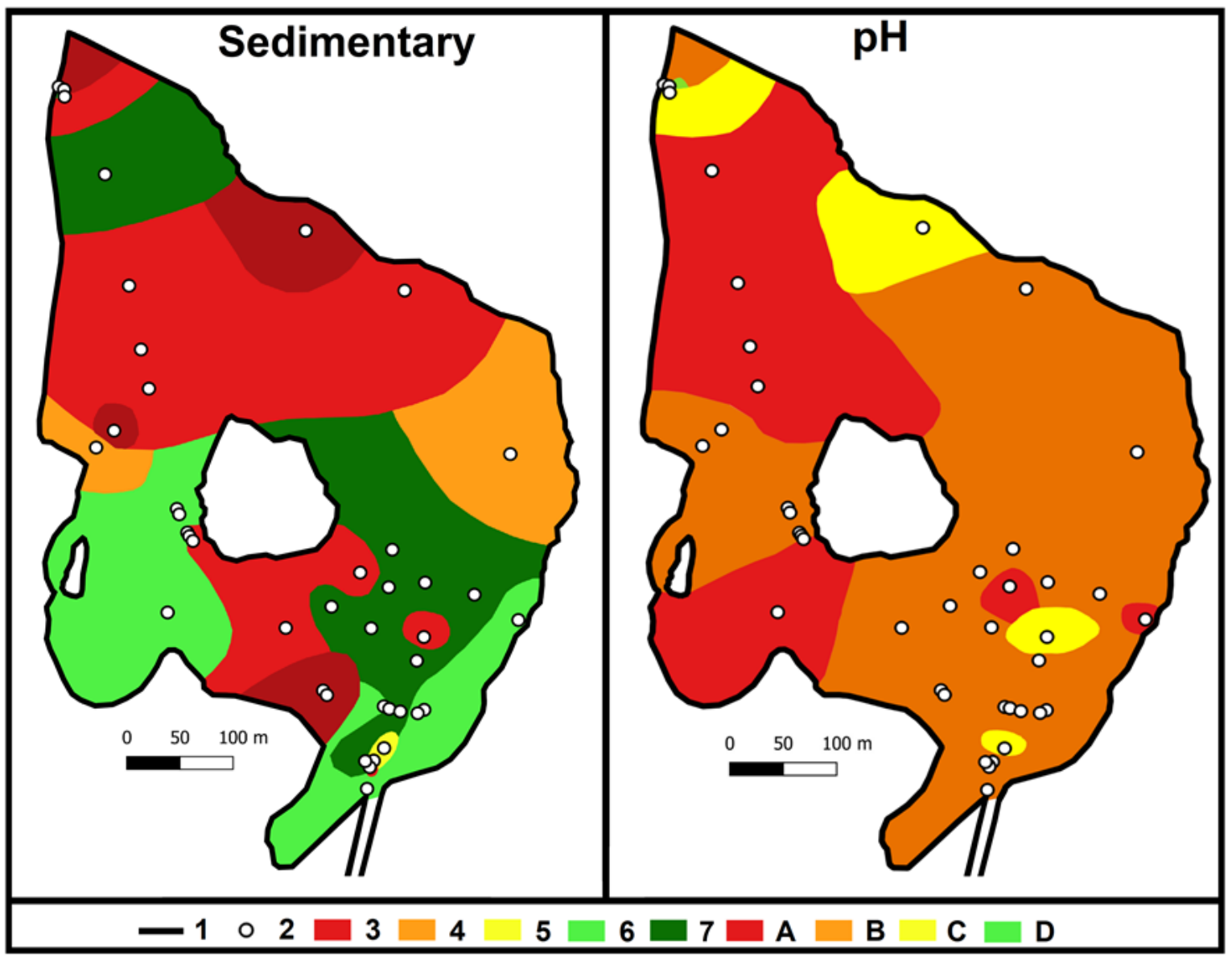

Figure 4. Suchedniów reservoir bottom sedimentary and $\mathrm{pH}$ map to $20 \mathrm{~cm}$ depth; Lithology:

1 - border of modern water reservoir, 2 - profiles and drillings, 3 - sand with single gravels, 4 - medium sand, 5 - fine sand, 6 - sandy silt, 7 - silt and clay; pH: A - strong acidic, B - acidic, C - lightly acidic, D - neutral [20]

Table 4. The content of selected heavy metals and the

values of the Igeo in the analyzed sediment samples

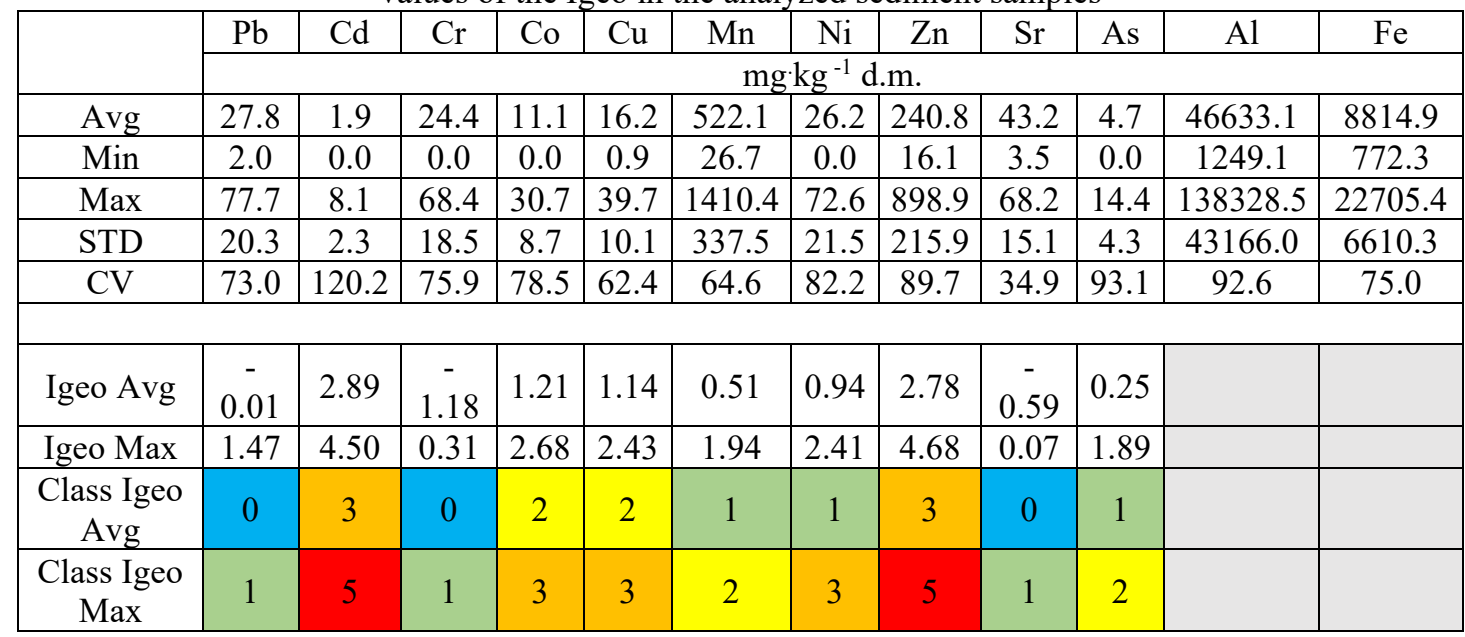




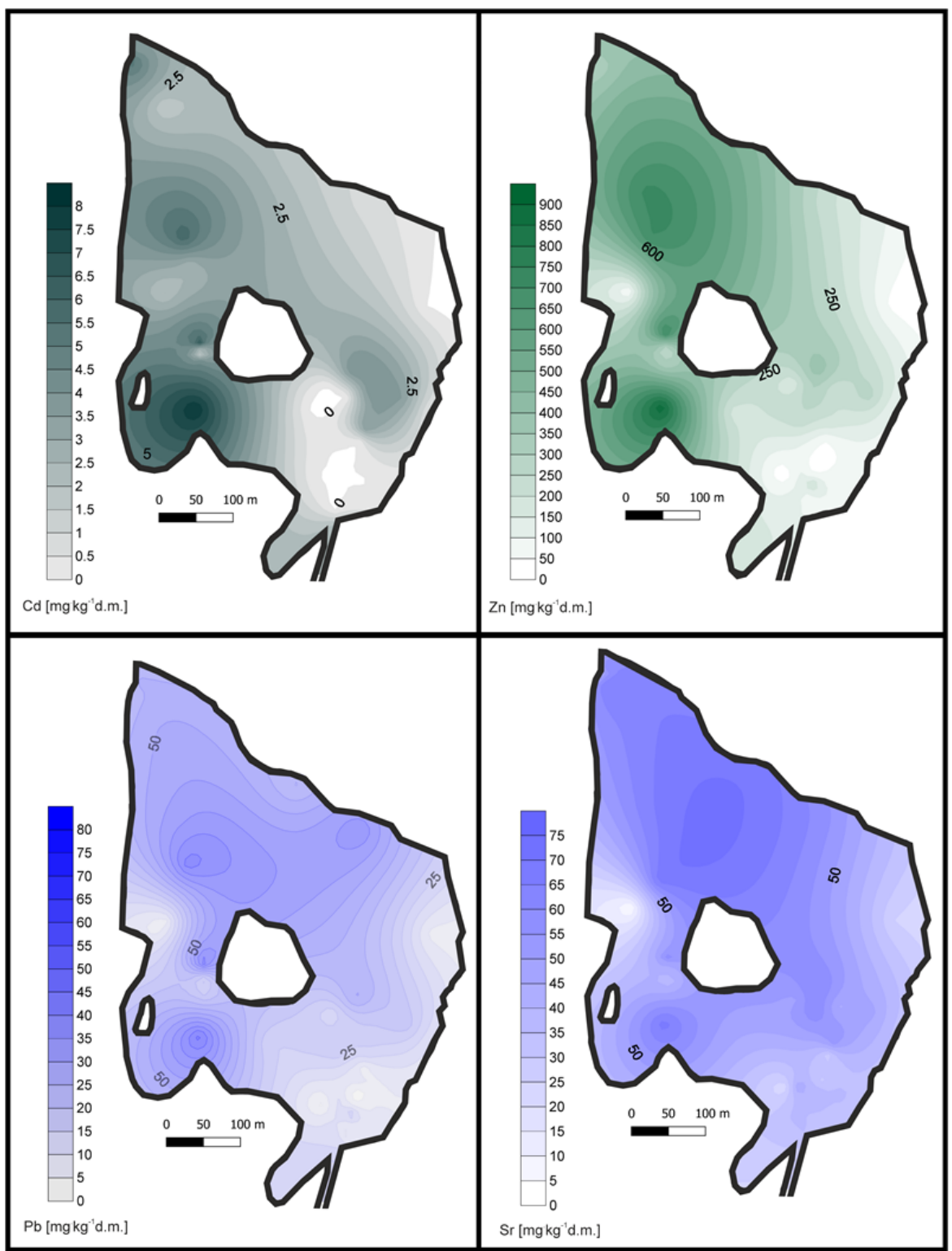

Figure 5. Spatial content of selected heavy metals

$(\mathrm{Cd}, \mathrm{Zn}, \mathrm{Pb}, \mathrm{Sr})$ in the Suchedniów water reservoir bottom

\section{CONCLUSIONS}

Before its dredging (until 2017), the Suchedniów water reservoir was characterized by a high rate of heavy metal contamination in its northern and western parts. It is related to the land use in the catchment and the reservoir development. The nature of the flow-through reservoir type also leads to the washout of contaminants from one part of it and the accumulation of trace elements in another. The concentration of pollutants can also be associated with the sediment type accumulated in the reservoir bottom as a result of various rapid (catastrophic) and long-term (secular) events [20].

\section{REFERENCES}

[1] Bielenin K. Starożytne górnictwo i hutnictwo żelaza w Górach Świętokrzyskich, Wydanie drugie, poszerzone i poprawione, Kieleckie Towarzystwo Naukowe, 1992.

[2] Orzechowski Sz. Zaplecze osadnicze i podstawy surowcowe starożytnego hutnictwa świętokrzyskiego, Kieleckie Towarzystwo Naukowe, Kielce, 2007.

[3] Przepióra P. Naturalne i historyczne zmiany zlewni Kamionki (Płaskowyż Suchedniowski), PhD thesis, Jan Kochanowski University in Kielce, 2017.

[4] Przepióra P., Kalicki T., Nowak E., Kusztal K., Houbrechts G., Pabian G., Peeters A., 2021. Historical mining remains preserved in the present-day relief of the European Hercynian Mountains - Casestudies from Holy Cross 
Mountains (Poland) and Ardennes (Belgium). Acta Geobalcanica, 7-3, pp 109-115.

[5] Kalicki T., Przepióra P., Kusztal P., Chrabąszcz M., Fularczyk K., Kłusakiewicz E., Frączek M. Historical and present-day human impact on fluvial systems in the Old-Polish Industrial District (Poland). Geomorphology, available online 12 February 2020. https://doi.org/10.1016/j.geomorph.2020.107062, 2020.

[6] Kalicki T., Frączek M., Przepióra P., Kusztal P., Kłusakiewicz E. \& Malęga E. Late Quaternary geomorphology and geoarchaeology in the rivers of the Holy Cross Mountains region, central Europe, Quaternary Research, Special Issue, pp 1-16, 2018.

[7] Piasta S. Leksykon Suchedniowa, Towarzystwo Przyjaciół Suchedniowa, Kielce, 2012.

[8] Bojakowska I., Sokołowska G. Geochemiczne klasy czystości osadów wodnych. Przegląd Geologiczny, 46 (1), pp 49-54, 1998.

[9] Loska K., Wiechula D., Korus I. Metal contamination of farming soils affected by industry. Environment International 30, pp. 159-165, 2004.

[10] Chen, C. W., Kao, C. M., Chen, C. F. \& Dong, C. D. Distribution and accumulation of metals in sediments of Kaoshiung Harbor,Taiwan, Chemosphere 66, pp 1431-1440, 2007.

[11] Kostecki J., Greinert A., Wasylewicz R., Adam R., Garbera B., Knap P., Ostapkowicz M., Stanisławiak B. Spatial distribution of heavy metals in the topsoil on roundabouts in Zielona Góra, Poland. Environmental Protection and Natural Resources 26 no 2(64), pp 1-8, 2015.

[12] Müller G. Index of Geoaccumulation in Sediments of the Rhine River. Geo. Journal, 2, pp 109-118, 1969.

[13] Müller G. Die Schwermetallbelastung der Sedimenten des Neckars und Seiner Nebenflu“sse. Chemiker-Zeitung 6, pp 157-64, 1981.

[14] Biesaga P., Kalicki T., Frączek M. \& Przepióra P. Gilberts delta in Suchedniów reservoir, 24. Kvarter, Brno, pp 14, 2018.

[15] Kalicki T., Przepióra P., Aksamit M., Biesaga P., Frączek M., Kłusakiewicz E., Grzeszczyk P., Chrabąszcz M. \& Kusztal P. Formy i osady Zalewu Suchedniowskiego (województwo świętokrzyskie) - wstępne wyniki, [in:] Cłapa T., Dawidowicz L. \& Szymański E.M. (ed.) Nauka dla środowiska, vol 3, Uniwersytet Przyrodniczy w Poznaniu, University of Technology in Poznań, pp 70-76, 2018.

[16] Kalicki T., Przepióra P., Aksamit M., Biesaga P., Frączek M., Kłusakiewicz E., Grzeszczyk P., Chrabąszcz M. \& Kusztal P. Zróżnicowanie osadów wypełniających Zalew Suchedniowski (województwo świętokrzyskie), [in:] Kostrzewski A., Stach A. \& Majewski M. (ed.) Geneza, Litologia i Stratygrafia Utworów Czwartorzędowych, vol. VII, Instytut Geoekologii i Geoinformacji UAM, Poznań, pp 69-73, 2018.

[17] Przepióra P., Kalicki T., Aksamit M., Biesaga P., Frączek M., Grzeszczyk P., Malęga E., Chrabąszcz M., Kłusakiewicz E., Kusztal P., Secular and catastrophic processes reflected in sediments of the Suchedniów water reservoir, Holy Cross Mountains (Poland). Geologos 25 (2) pp 139-152, 2019.

[18] www. facebook.comSuchedniowWczoraj

[19] Bąk Ł., Górski J. \& Szeląg B. Wpływ kaskady zbiorników małej retencji Suchedniów i Rejów na redukcję fali wezbraniowej na rzece Kamionka, Acta Sci. Pol., Formatio Circumiectus, vol. 11, no. 1, pp 13-22, 2012.

[20] Przepióra P., Kalicki T., Aksamit M., Biesaga P., Frączek M., Grzeszczyk P., Malęga E., Chrabąszcz M., Kłusakiewicz E., Kusztal P., Secular and catastrophic processes reflected in sediments of the Suchedniów water reservoir, Holy Cross Mountains (Poland). Geologos 25 (2), pp 139-152, 2019.

[21] Salminen R., (Chef Editor) Batista M. J., Bidovec M., Demetriades A., De Vivo B., De Vos W., Duris M., Gilucis A., Gregorauskiene V., Halamic J., Heitzmann P., Lima A., Jordan G., Klaver G., Klein P., Lis J., Locutura J., Marsina K., Mazreku A., O’Connor P.J., Olsson S.Å., OttesenR.T., Petersell V., Plant J.A., Reeder S., Salpeteur I., Sandström H., Siewers U., Steenfelt A. and Tarvainen T. FOREGS Geochemical Atlas of Europe, Part 1: Background Information, Methodology and Maps. Geological Survey of Finland, Espoo, pp 526, 2005.

[22] Sałata, A., Bąk, Ł., Chmielowski, K., Rabajczyk, A. Metal pollution of sediments in small water reservoirs in the Kielce Highland (South Eastern Poland). Archives of Environmental Protection 45 (2), pp 12-21, 2019 